\title{
NEKILNOJAMOJO TURTO INVESTICINIAI FONDAI: VIETA INVESTICINIŲ FONDŲ İVAIROVE்JE
}

\author{
Juozas Bivainis, Lina Volodzkienè \\ Vilniaus Gedimino technikos universitetas, Sauletekio al. 11, LT-10223 Vilnius, Lietuva \\ El.paštasvvfsevk@vv.vgtu.lt \\ Iteikta 2008-03-04; priimta 2008-07-03

\begin{abstract}
Santrauka. XXI a. valstybių ekonomika ir socialinis sektorius vargiai įsivaizduojami be investicinių fondų. Dideja investicijų mastas, fondų ịvairovė ir investavimo galimybès. Iš ịvairių investicinių fondų tipų bene prieštaringiausiai vertinami nekilnojamojo turto investiciniai fondai. Straipsnyje pateikti nekilnojamojo turto investicinių fondų, kaip vienos iš galimų investavimo alternatyvų, tyrimo rezultatai. Šio tipo fondų vaidmeniui ir reikšmei įvertinti taikytas trijų kriterijų derinys: investicijų pelningumas, jų rizika ir investicijų i ịvairių rūšių turtą pelningumo koreliacija. Pagal šiuos kriterijus nustatyti nekilnojamojo turto investicinių fondų kaip investicijų portfelio diversifikavimo priemonès poveikio investavimo rezultatams dėsningumai.
\end{abstract}

Reikšminiai žodžiai: investiciniai fondai, nekilnojamojo turto investiciniai fondai, investicijų portfelio struktūra, pelningumas, rizika.

\section{REAL ESTATE INVESTMENT TRUSTS: A PLACE IN THE DIVERSITY OF INVESTMENT FUNDS}

\author{
Juozas Bivainis, Lina Volodzkienè \\ Vilnius Gediminas Technical University, Sauletekio al. 11, LT-10223 Vilnius, Lithuania \\ E-mail:vvfsevk@vv.vgtu.lt
}

Received 4 March 2008; accepted 3 July 2008

\begin{abstract}
Economies and social sectors of the $21^{\text {st }}$ century states are hard to picture without investment funds. The extent of investments, the variety of funds as well as the opportunities for investment are constantly increasing. Of this variety, the real estate investment trusts are subject to the most controversial opinions. This article includes the results of a research on REITs as an alternative for investment. A three-criterion set - return on investments, risk and correlation of return with investments in different types of assets - has been used to assess the role and the significance of such trusts. According to these criteria, patterns of influence of REITs as an investment portfolio diversification tool on investment results have been determined.
\end{abstract}

Keywords: investment funds, real estate investment trusts, investment portfolio structure, return, risk. 


\section{Ivadas}

Kiekvienos gerovès valstybès tikslas - užtikrinti socialinę ir ekonominę pažangą, didinti gyventojų gerovę. Tam igyvendinamos ịvairios priemonès, spartinančios ekonomini augimą, taip pat sudarančios sąlygas piliečiams savo gerove pasirūpinti patiems. Viena iš šio tipo svarbių priemonių investiciniai fondai, suteikiantys galimybę gyventojams investuoti laisvas lèšas ir taip apsaugoti jas nuo nuvertėjimo, gauti papildomų pajamų. O tai ypač aktualu perspektyvos požiūriu (tipinè situacija - labai sumažèjusios ar net prarastos darbo pajamos dèl žmogaus amžiaus).

Ekonomikos globalizacija, naujos informacinès technologijos ir kiti XX a. pabaigos ir XXI a. pradžios reiškiniai panaikino daugybę barjerų tarp pasaulio valstybių bei ịvairių regionų rinkų ir taip kardinaliai išplètè geografines investavimo galimybes. Savo ruožtu keičiasi ir investiciniai fondai, ne tik savo veiklos mastu, bet ir turiniu. Itvairiuose pasaulio kraštuose veikia investiciniai fondai, kurie skiriasi daugybe požymių: investicijų politika, organizacine forma, investicijų pobūdžiu, investavimo objektais, pelningumu, patikimumu ir kt. Šalia klasikinių fondų, investuojančių $i$ vertybinius popierius, vis dažniau randasi fondų, investuojančių ị nekilnojamąji turtą. Jų atžvilgiu išsakomos gana skirtingos, net prieštaringos nuomonès. Tai ir paskatino panagrinèti nekilnojamojo turto investicinių fondų vaidmenį bei vietą tarp kitų investicinių fondų ir investavimo priemonių. Sraipsnyje pateikti nekilnojamojo turto investicinių fondų, kaip vienos iš galimų investavimo alternatyvų, tyrimo rezultatai. Tyrimui taikyti šie metodai: mokslinès literatūros analizè, statistinių duomenų analizè, lyginamoji analizè, loginè analizè.

\section{Investicinių fondų ịvairovẻ}

Lietuvos Respublikos investiciju įstatyme (1999) investicijos apibrežiamos kaip piniginès lešos ir įstatymais bei kitais teisès aktais nustatyta tvarka ịvertintas materialusis, nematerialusis ir finansinis turtas, kuris investuojamas siekiant iš investavimo objekto gauti pelno (pajamų), socialini rezultatą (švietimo, kultūros, mokslo, sveikatos ir socialinès apsaugos bei kitose panašiose srityse) arba užtikrinti valstybès funkcijų igyvendinimą. Tame pačiame ìstatyme investavimas apibūdinamas kaip įstatymo nustatytais būdais atliekami investuotojo veiksmai, kuriais jis igyja nuosavybès teisę arba kreditoriaus reikalavimo teisę į investavimo objektą arba teisę šs̆ objektą valdyti ir naudoti. Investavimo objektais gali būti nuosavas ūkio subjekto kapitalas, visų rūšių vertybiniai popieriai, ilgalaikis materialusis turtas ir ilgalaikis nematerialusis turtas.

Investicijos gali būti tiek ị finansinị turtą, tiek ị materialųji. Finansinio turto, kaip investavimo objekto, G. Kancerevyčius (2006: 277) išskiria tokias rūšis: fiksuotu pajamu finansiniai instrumentai (angl. fixed income securi- ties) arba skolos instrumentai (angl. debt securities), nuosavybes instrumentai (angl. equities), išvestiniai instrumentai (angl. derivatives), fondai. Materialiųjų investicijų dažniausi objektai yra tokie: nekilnojamasis turtas, meno kūriniai, brangakmeniai, antikvariatas ir kt.

Mokslinëje literatūroje nagrinejjant investicinių fondų apibrèžimus išskiriamos trys pagrindinès investavimo priemonès: pinigų rinkos priemonés, obligacijos, akcijos. Pinigu rinkos priemone laikoma tokia priemonè, kurią galima per trumpą laiką ir be nuostolių investuotam kapitalui paversti pinigais. Pinigų rinkos priemonès (grynieji pinigai, indèliai bankuose, iždo vekseliai ir pan.) yra trumpalaikès investicijos, todèl tikimybé, kad per trumpą investavimo laikotarpị rinkos kaina nenumatytai kis nepalankia kryptimi, labai maža. Atitinkamai maža rizika, o būsimą pelną, nors ir nedideli, galima žinoti iš anksto. Pažymètina, kad pinigų rinkos priemonès nèra gera apsauga nuo infliacijos dèl mažo pelningumo (Vertybinių popierių komisija 2006). Obligacijos traktuotinos kaip paskola už nustatytas palūkanas jas išleidusiam subjektui (Vyriausybė, bankas ar kitas ūkio subjektas). Vienas iš investavimo į obligacijas pranašumų yra tas, kad žinoma, kokios pajamos iš investicijos bus gautos. Pastebètas dèsningumas, kad obligacijų kaina kyla, kai palūkanų normos rinkoje krinta, ir atvirkščiai. Be to, kuo nepatikimesnis obligacijų emitentas, tuo didesnès palūkanos. Obligacijų turètojai laikomi įmonès kreditoriais, o bendrovès akcijų turintieji yra bendrovès akcininkai. Tačiau akcininkas, skirtingai nei obligacijų turètojas, nežino, kiek pajamų gaus iš akcijų.

Lietuvos Respublikos kolektyvinio investavimo subjektų istatyme (2003) investicinis fondas apibrežiamas kaip bendrosios dalinès nuosavybès teise juridiniams ar fiziniams asmenims priklausantis turtas, kurio valdymas perduotas valdymo ịmonei. Mokslinèje literatūroje vartojamas investicinio fondo apibrěžimas - investicinè bendrovė, kuri pritraukia fizinių ir juridinių asmenų lěšas bei investuoja jas Ł̇ ịvairius vertybinius popierius - nèra tikslus ir reikalauja patikslinimo naujausių investavimo alternatyvų atžvilgiu. Taigi šiame straipsnyje investicinis fondas traktuojamas kaip investiciné bendrovè, kuri pritraukia fizinių ir juridinių asmenų lëšas bei investuoja i finansinị turtą (akcijas, obligacijas) ir materialujji turtą (nekilnojamaji turta).

Daugelio šalių ịstatymai Ł̣pareigoja fondus veikti visiškai atvirai. Veiklos skaidrumas ir informacijos akcininkams atskleidimas - vienas pagrindinių reikalavimų investiciniams fondams visame pasaulyje. Dar vienas svarbus teisinio reguliavimo aspektas yra investicinio fondo veiklos rizikos ribojimai. Šie ribojimai yra griežti, tačiau investicinio fondo vadovybė neatsako už nuostolius, kuriuos fondas gali patirti dèl rinkų nestabilumo, investavimo priemonių kurso kritimo ar kitu tiesiogiai su investicinio fondo valdymo institucijų veikla nesusijusių priežasčių. Investicinio fondo paskirtis - padeti investuoti ir tvarkyti kolektyvines investici- 
jas (Čepinskis, Kuzmickas 1997: 16). Paprastai investicinių fondų îstatai gana tiksliai nustato produktus, ị kuriuos bus investuojama, ir investavimo sąlygas. Savo ruožtu investuotojas, įsigydamas investicinio fondo akcijas, raštiškai sutinka prisiimti konkrečią rizikos dali.

Investicinio fondo kapitalas formuojamas iš akcininkų investicijų $i \mathrm{tam}$ tikras fondo reglamente nustatytas finansines priemones. Šių priemonių verte pasiskirsto investuotojams pagal jiems procentiškai priklausančias investicinio fondo santykines dalis. Investicinio fondo turto vertè kinta priklausomai nuo vertybinių popierių rinkos kainų. Kartu kinta ir investuotojų turimų akcijų kaina. Investuotojas, parduodamas akcijas, uždirba arba patiria nuostolių priklausomai nuo to, kaip pasikeité fondo investicijų vertè rinkoje per investavimo laikotarpi.

Mokesčiu lengvatos, investicinio portfelio diversifikacija, profesionalus valdymas - svarbiausios priežastys, dè kuriu žmonés renkasi investicinius fondus. Tai plačiausiai paplitusi kolektyvinio investavimo forma. Istoriškai pirmųju investicinių fondų paskirtis buvo stambių investuotojų kon- sultavimas. Šiuo metu veikiančių ịvairiausių investicinių fondų paslaugos padeda pasiekti labai skirtingus investuotojų tikslus ir poreikius. Investiciniai fondai klasifikuojami pagal ịvairius kriterijus: operacinę struktūra, gautu pajamu paskirstyma, investiciju politika, įmoniu, i kurias investuojama, kapitalizacija, fondo organizavimo forma, investavimo objektus, investiciju pobūdį ir kt. (1 pav.).

Investiciniai fondai gali veikti kaip atvirieji ir uždarieji priklausomai nuo savo operacinès struktūros. Tai bazinis investicinių fondų požymis. Investuotojai gali lengvai tapti atviruju fondu veiklos dalininkais arba palikti fondą. Tokią galimybę jiems suteikia fondo investavimas į kapitalo rinkose parduodamus likvidžius finansinius instrumentus. Investuotojais tokiuose fonduose gali būti bet kokie fiziniai ir juridiniai asmenys, norintys investuoti savo lěšas. Investuotojų skaičius atviruosiuose investiciniuose fonduose neribojamas (Čepinskis, Kuzmickas 1997: 10-11). Atvirieji fondai išleidžia paprastąsias akcijas - taip kaupia pinigines lèšas. Akcijų skaičius nèra fiksuotas ir nuolat kinta, nes šie fondai privalo bet kada išpirkti savo akcijas kaina, lygia

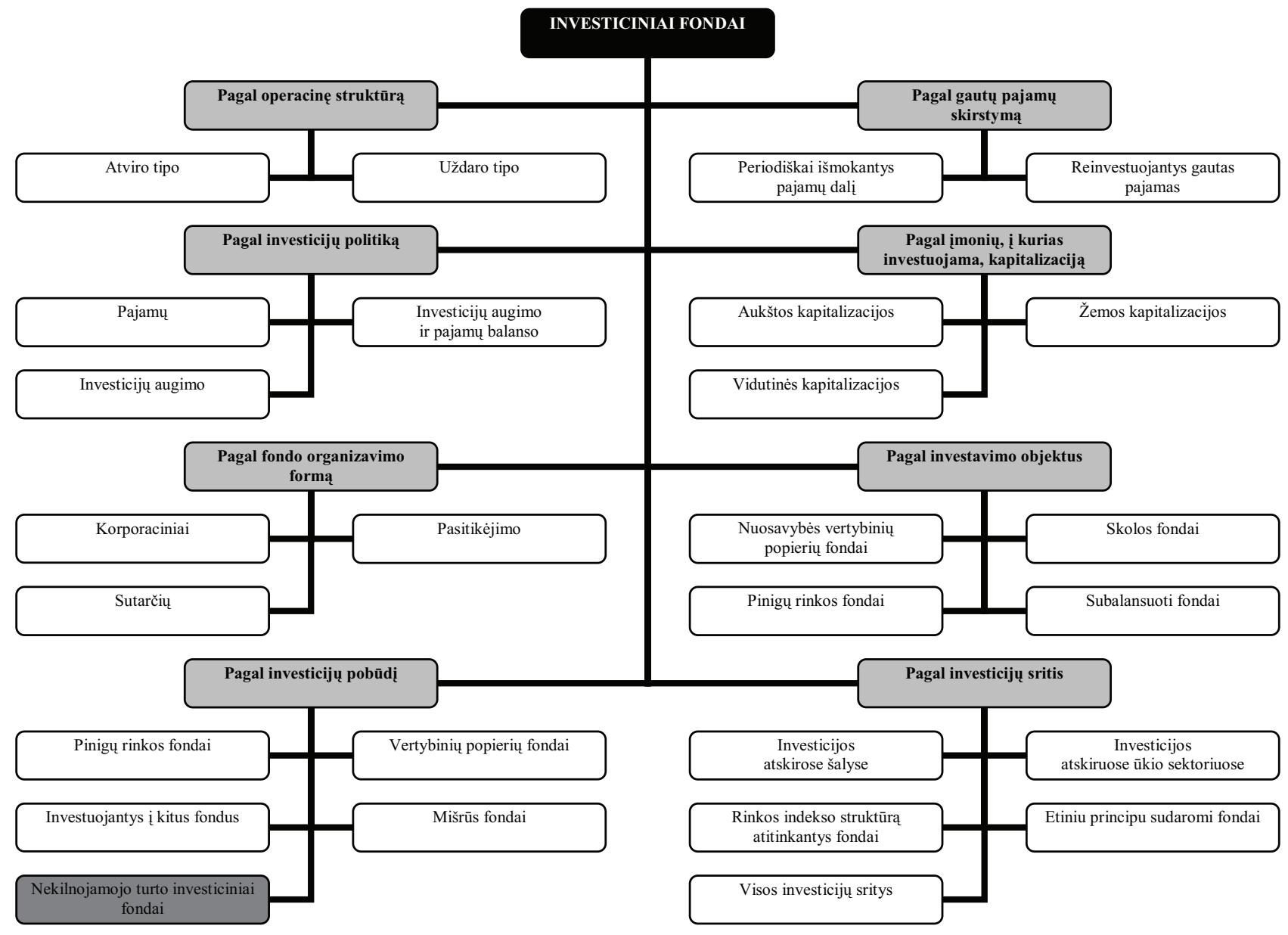

1 pav. Investicinių fondų klasifikavimo schema (Mačerinskienè, Volodzkienè 2006)

Fig. 1. Classification scheme of investment funds 
grynajai aktyvo vertei, t. y. pagal rinkos kursą. Atvirojo tipo investicinio fondo apimtis nèra ribojama - gali būti didinama, išleidžiant naujas akcijas. Uždaruosiuose investiciniuose fonduose investuotojų skaičius dažniausiai ribotas ir fiksuotas. Šių fondų veikla paprastai susieta su ilgalaikemis investicijomis, kurių likvidumas nèra labai aukštas (Čepinskis, Kuzmickas 1997: 11). Uždarụjų fondų lèšos formuojamos išleidžiant paprastąsias ir privilegijuotąsias akcijas, taip pat obligacijas. Akcijos išleidžiamos tik vieną kartą pagal iš anksto nustatytą jų bendros vertès dydį. Jų skaičius fiksuotas ir gali būti padidintas tik tam tikrais atvejais. Fondas savo akcijų neišperka, bet jomis galima prekiauti biržoje, jei jos kotiruojamos, ar užbiržinejje rinkoje.

Investiciniai fondai steigiami kaip ribotos atsakomybès ¿̨monès. Dalis investicinių fondų veikia kaip pasitikèjimo tipo įmonès (angl. trust companies). Iprasta pagal organizavimo struktūrą išskirti tokių tipų investicinius fondus (Snieška, Pekarskienè 1999: 76): korporaciniai fondai; pasitikejjimo fondai; sutarčių fondai. Korporaciniai fondai - tai plačiausiai paplitusi fondų organizavimo forma. Tokie investiciniai fondai yra akcinès bendrovès, investuojančios ị kitų įmonių vertybinius popierius ir gautas pajamas paskirstančios savo akcininkams dividendų forma. Akcininkai, kaip ir bet kurioje akcineje bendroveje, prisideda prie fondo valdymo. Fondo aktyvų portfelį valdo nepriklausoma turto valdymo įmonè. Pasitikéjimo fondai steigiami pasirašant sutartị tarp valdymo įmonès ir patikètinio, atsakančio už fondo turtą ir veiklą. Valdymo įmonè valdo fondo aktyvų portfelị ir atlieka administravimo procedūras. Toks funkcijų pasiskirstymas yra papildoma investicinio fondo ir jo investuotojų apsauga. Pažymètina, kad kai kurių šalių įstatymai draudžia steigti pasitikèjimo fondus, jose investiciniai fondai steigiami sutarčiu forma. Šio investicinio fondo aktyvus valdo valdymo įmoné, o atsakingas už aktyvus yra bankas ar kitokia kredito organizacija. Investicinio fondo investuotojai nèra akcininkai, o tik dalininkai, turintys teisę i investicinio fondo pajamas, kapitalo prieaugi, bet neprisidedantys prie fondo valdymo.

Pasaulio praktikoje skiriamos keturios pagrindinès fondų pagal investavimo objektus rūšys: nuosavybès vertybiniu popieriu fondai (angl. stock fund / equity fund), kurių didžiąją investicijų portfelio dalị sudaro akcijos; skolos fondai (angl. bond fund), kurių didžiąją investicijų portfelio dali sudaro skolos vertybiniai popieriai; pinigu rinkos fondai (angl. money market fund), kurių didžiąją investicijų portfelio dali sudaro pinigų rinkos priemonès, tokios kaip banku akceptai, valstybès ar savivaldybès vekseliai ir pan.; subalansuoti (angl. balanced fund) arba mišrūs fondai (angl. mixed fund / hybrid fund) - investicijų portfelį sudaro nuosavybès, skolos ir pinigų rinkos priemonès.

Investicinių fondų ịstatai turi apibrèžti fondo investicijų sritị ir strategiją. Juose pateikta informacija leidžia investuotojui išsirinkti priimtinas investavimo paslaugas.
Investuotojas gali pasirinkti fondus, taikančius ịvairias strategijas, kurios lemia nevienodus investavimo rezultatus. Taip patenkinamos įvairios investuotojų reikmės. Nuo fondo pasirinktos investavimo strategijos priklauso jo investicijų portfelio sandara. Pagal investavimo strategiją skiriami tokie investicinių fondų tipai (Čepinskis, Kuzmickas 1997: 10-11): pinigų rinkos; vertybinių popierių; mišrūs; indekso, nekilnojamojo turto investiciniai fondai. Pinigu rinkos fondai - tai fondai, investuojantys ị pinigų rinkos instrumentus. Tai gali būti ir atskiri pinigų rinkos produktai (skirtinga valiuta), kartais investicijų pasiskirstymas fonde apribojamas konkrečia valiuta (pavyzdžiui, visos investicijos tik $\mathfrak{i}$ JAV dolerius). Vertybiniu popieriu fondai dažniausia investuoja ị akcijas ir obligacijas, bet yra investuojančių ir tik $\mathfrak{i}$ atskirų rūšiu vertybinius popierius - akcijas ar obligacijas. Mišrūs fondai gali investuoti ị ịvairių formų kapitalą. Ši fondų rūšis nèra paplitusi, nes fondas praranda specializaciją, kuri yra vienas iš svarbiausių investiciniu fondų bruožų.

Fondai, investuojantys j̣ akcijas, skirstomi taip (Snieška, Pekarskienè 1999: 76-77):

- Augimo fondai. Pagrindinis siekis - ilgalaikis kapitalo augimas. Investuojama ị akcijas įmonių, turinčių geras pelno didinimo perspektyvas. Kasmetinès pajamos iš dividendų nèra svarbiausias kriterijus.

- Agresyvaus augimo fondai. Pagrindinis tikslas - greitas kapitalo prieaugis, investuojama ị kylančiu įmonių akcijas, fondo aktyvų portfelio struktūra dažnai kintama. Kasmetinès pajamos yra nedidelès, portfelio akcijų kursas nestabilus, todèl svarbu pasirinkti tinkamą pirkimo ir pardavimo laiką.

- Pajamu fondai. Priešingai nei augimo ir agresyvaus augimo fondų, jų pagrindinis tikslas - dideli dividendai. Investuojama ị gerai žinomų ịmonių akcijas, duodančias daug pajamų.

- Augimo ir pajamu fondai. Pagrindinis tikslas - nuolatinis kapitalo prieaugis ir didelès kasmetinès pajamos. Tipinị fondo portfelị sudaro gerai žinomų įmonių akcijos, pasižyminčios kapitalo augimu ir stabiliomis pajamomis.

- Specializuoti fondai. Skiriamos tokios jų atmainos: 1) tarptautiniai fondai, investuojantys ị užsienio emitentų vertybinius popierius; 2) sektoriaus fondai, investuojantys ị tam tikrą sektorių; 3) subalansuotieji fondai, kurie yra panašūs ị augimo ir pajamų fondus, tačiau skiriasi tuo, kad tarp portfelio vertybiniu popierių palaikoma iš anksto nustatyta proporcija; 4) indeksų fondai, investuojantys ị tuos vertybinius popierius ir tokiomis proporcijomis, kaip ir pasirinkto indekso.

Obligaciju fondai investuoja ị kredito vertybinius popierius, tuo garantuodami savo investuotojams nuolatines 
pajamas. Investuotojams, siekiantiems nuolatinių pajamų ir nelinkusiems rizikuoti, šie fondai yra tinkamiausi. Smulkiau šie fondai skirstomi ị iždo, korporacijų ir municipalinių obligacijų fondus. Investicijos į obligacijų fondus nuo investicijų i obligacijas skiriasi vienu svarbiu aspektu: priešingai nei obligacijų atveju, investicijas galima susigrąžinti bet kuriuo metu, fondui parduodant akcijas. Investicijos i obligacijų fondus yra ne tokios rizikingos.

J. Čepinskis, D. Kuzmickas (1997: 11) pagal investicijų politiką išskiria tokius investicinius fondus: investicijų augimo, pajamu ir balansuoti tarp augimo bei pajamų. Šis skirstymas panašus ị fondų skirstymą pagal gautų pajamų išmokejjimą - periodiškai išmokantys pajamas ir reinvestuojantys. Pirmųjų svarbiausias bruožas - periodinis pajamų srautas, antrujuc - didesnis kapitalo prieaugis.

Nemaža fondų ívairove ir pagal investavimo sritis. Plačiausios investavimo galimybès - visos šalys ir visi ūkio sektoriai. Kiti fondai koncentruojasi ị tam tikras šalis ir sektorius. Etiniu principu sudaromi fondai pirmenybę teikia investicijoms ị socialiniu požiūriu patrauklias pramonès šakas ar verslą, pavyzdžiui, neinvestuoja ị alkoholio ar tabako pramonę (Čepinskis, Kuzmickas 1997: 11).

Nekilnojamojo turto fondai labiausiai skiriasi nuo kitų rūšių investicinių fondų. Jų veiklos specifika ta, kad didžioji dalis investicijų yra glaudžiai susijusi su nekilnojamuoju turtu. Šių fondų populiarumas išaugo supratus, kad jie yra patrauklus rizikos ir pelno kompromisas.

\section{Nekilnojamojo turto investicinių fondų veiklos specifika}

Pagrindiniai investavimo ị nekilnojamąjị turtą būdai yra du: nekilnojamojo turto nuosavybès igijimas ir nekilnojamojo turto investiciniai fondai (toliau tekste - REIT). REIT (real estate investment trust) turtą sudaro nekilnojamasis turtas ir su nekilnojamuoju turtu susiję finansiniai instrumentai. REIT pajamas gauna iš nekilnojamojo turto - turimo nuosavybès forma, valdomo, finansuojamo. Kancerevyčiaus (2006: 695) teigimu, REIT yra uždarojo tipo investiciniai fondai, kurie gautas ar skolintas lèšas investuoja ị nekilnojamąji turtą. Mokslinejje literatūroje išskiriami trys REIT tipai:

- nuosavybès REIT (angl. equity REITs) - tai labiausiai paplitęs nekilnojamojo turto investicinių fondų tipas, investuojantis ir (arba) valdantis nekilnojamąji turtą, o pajamas gaunantis iš įvairių rūšių tipo nekilnojamojo turto nuomos;

- hipotekos REIT (angl. mortgage REITs) - tai fondai, kurie suteikia statybų ir hipotekos paskolas nekilnojamojo turto investuotojams;

- mišrūs (angl. hybrid REITs) - tai fondai, perkantys nekilnojamąji turtą ir finansuojantys jo statybas bei pirkimą.

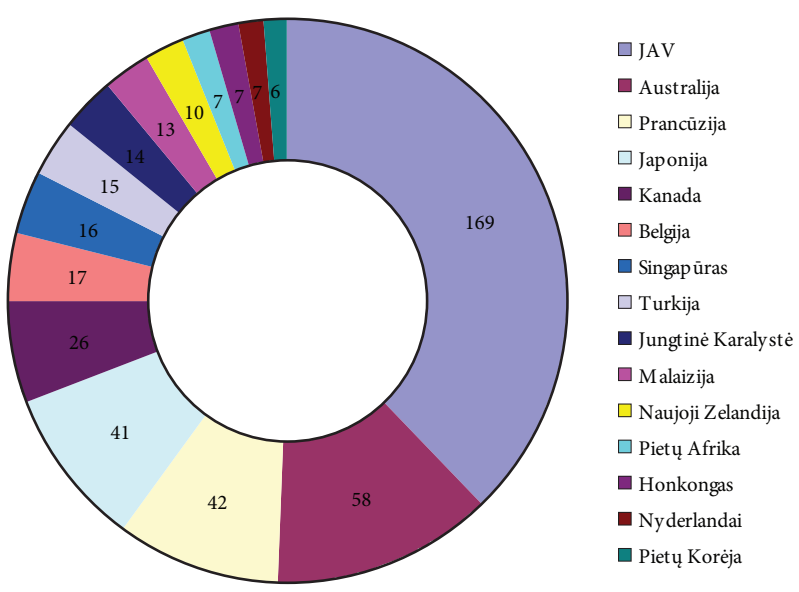

2 pav. REIT skaičius pagal valstybes (2007 m.)

Fig. 2. Total REITs by country (2007)

Šaltinis: Global REIT Report 2008

Pirmieji REIT atsirado JAV 1960 m., išleidus jų veiklą reglamentuojančius teisès aktus. G. Kancerevyčius (2006: 695) pažymejjo, kad REIT smulkiesiems investuotojams sudaro galimybę dalyvauti nekilnojamojo turto versle. REIT valdomo nekilnojamojo turto rūšys įvairios: gyvenamosios patalpos, prekybos ir įstaigų centrai, pramoniniai pastatai, sveikatos centrai, viešbučiai ir kt. Finansiniai jų instrumentai tokie: paskolos nekilnojamojo turto projektams igyvendinti, hipoteka ir pan. REIT yra uždrausta pajamas gauti vien tik iš pasyvių šaltinių, tokių kaip nuomos pajamos, palūkanos, dividendai, pardavimo pelnas. REIT atleidžiami nuo pelno mokesčio tik tada, kai didžioji dalis pajamų yra gaunama iš nekilnojamojo turto ir didžioji dalis pelno atitenka akcininkams. Žvelgiant $\mathfrak{i}$ istorinius faktus, nuo 1970 m. REIT išgyveno smarkaus nuosmukio periodą, tačiau nuo 1990 m. jie pradejo sparčiai augti. Palankiais metais REIT pelningumas siekè 10-20 proc. ir daugiau per metus, bet būta ir nuostolingų metų. Pavyzdžiui, vidutinis REIT pelningumas 1990 m. buvo 17,4 proc., o 1991 m. 35,7 proc. (Kancerevyčius 2006: 695).

JAV pavyzdžiu pasekė ir kitos šalys. Šiuo metu REIT aktyviai veikia 15 valstybių (2 pav.). Išaugo ir investicijų i REIT mastas (3 pav.). $2007 \mathrm{~m}$. REIT valdomas turtas (kapitalizacijos lygis) sudare $762559 \mathrm{mln}$. JAV dolerių, o 2006 m. - 600667 mln. JAV dolerių (Global REIT Report 2008). Visgi REIT santykinai yra nedaug, palyginti su kitų rūšių investiciniais fondais (4 pav.).

Pastarųjų metų REIT pelningumas ịvairiose valstybèse varijuoja nuo 10 proc. iki beveik 73 proc. 5 pav. parodytas REIT vienerių metų pelningumus ir pastarųjų trejų metų pelningumas. 


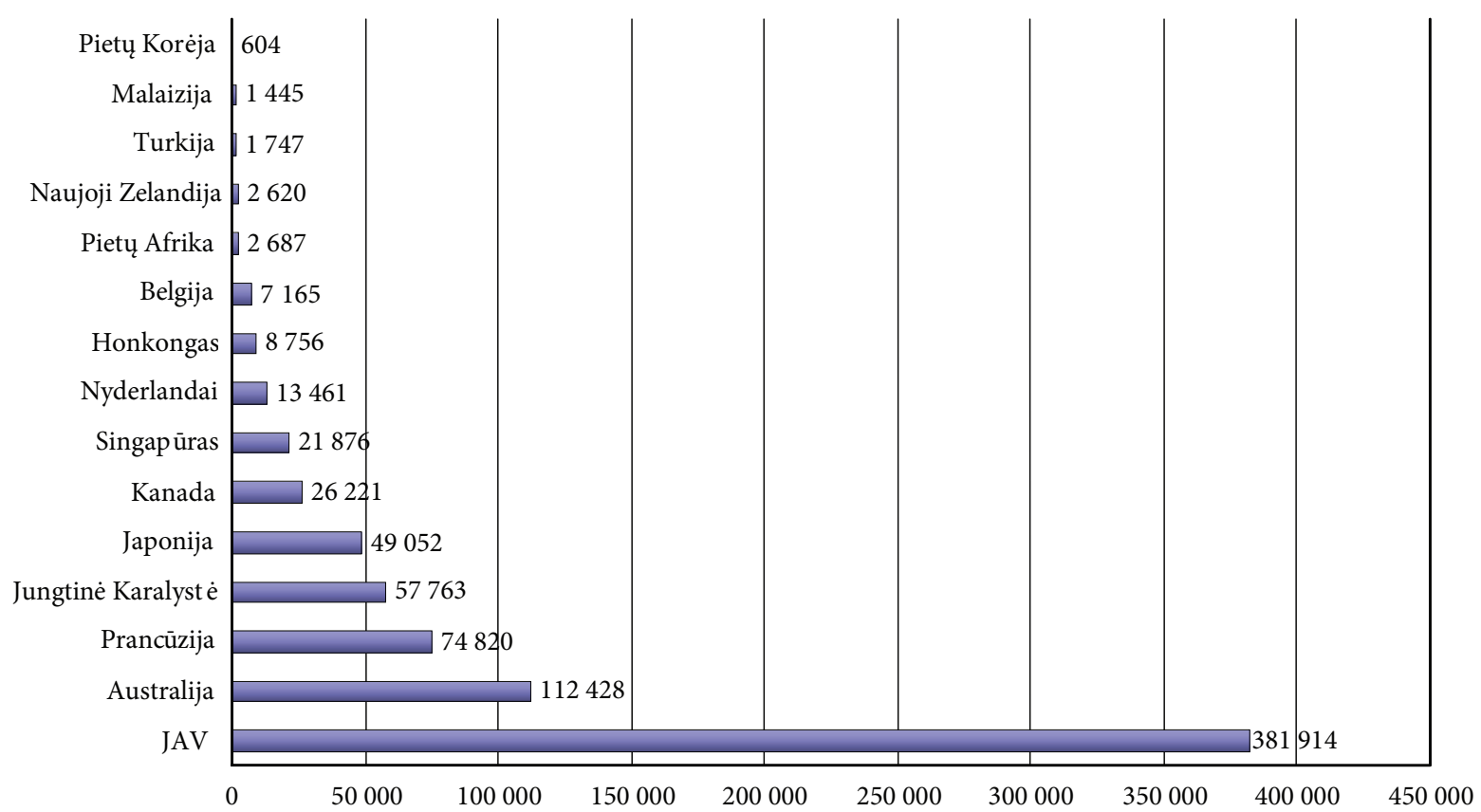

Šaltinis: Global REIT Report 2008

3 pav. REIT valdomas turtas (kapitalizacijos lygis) pagal valstybes (2007 m.), mln. JAV doleriu

Fig. 3. Assets of REITs (capitalisation level) by state (2007), USD millions

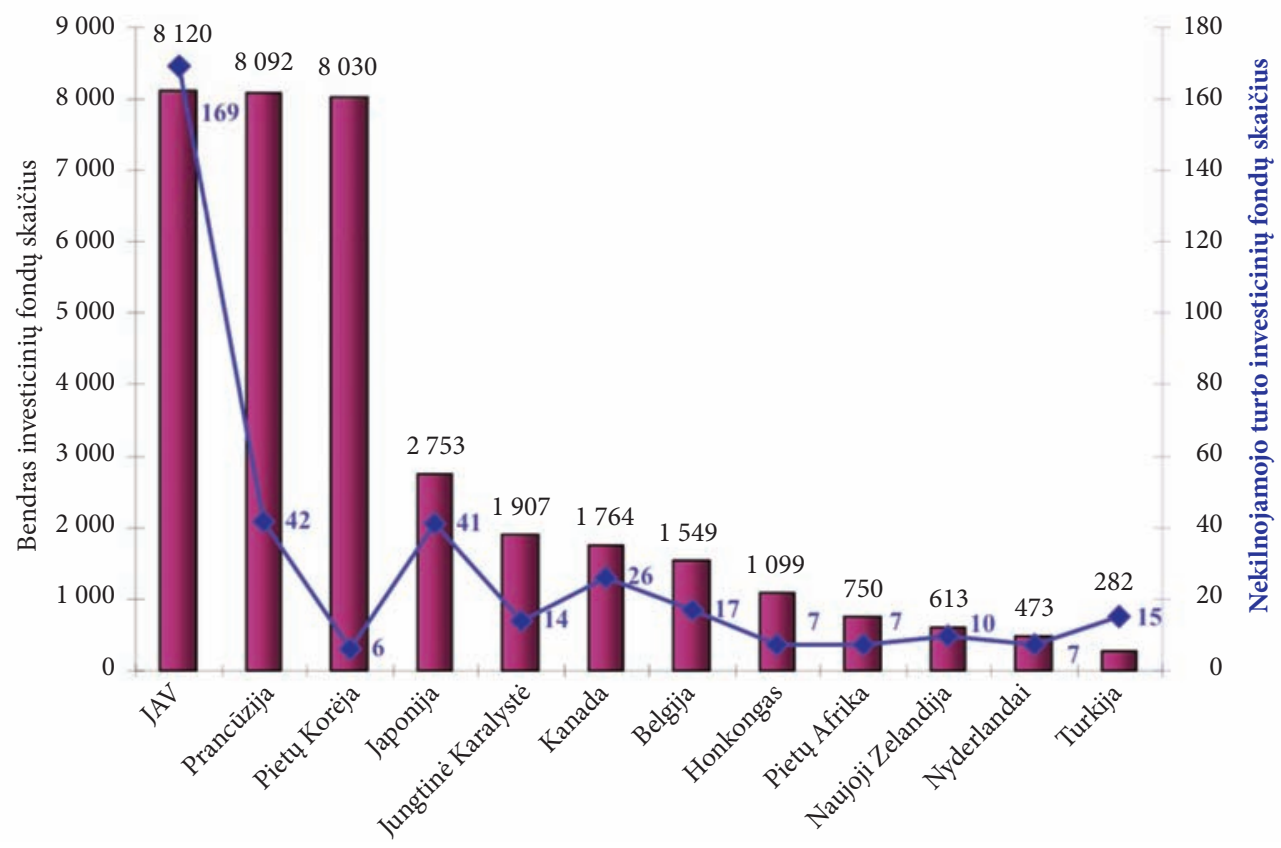

Šaltinis: Worldwide Number of Mutual Funds 2007; Global REIT Report 2008

4 pav. REIT (2007 m.) ir visų investicinių fondų skaičius (2006 m.) pagal valstybes

Fig. 4. Total REITs (2007) and all investment funds (2006) by state 


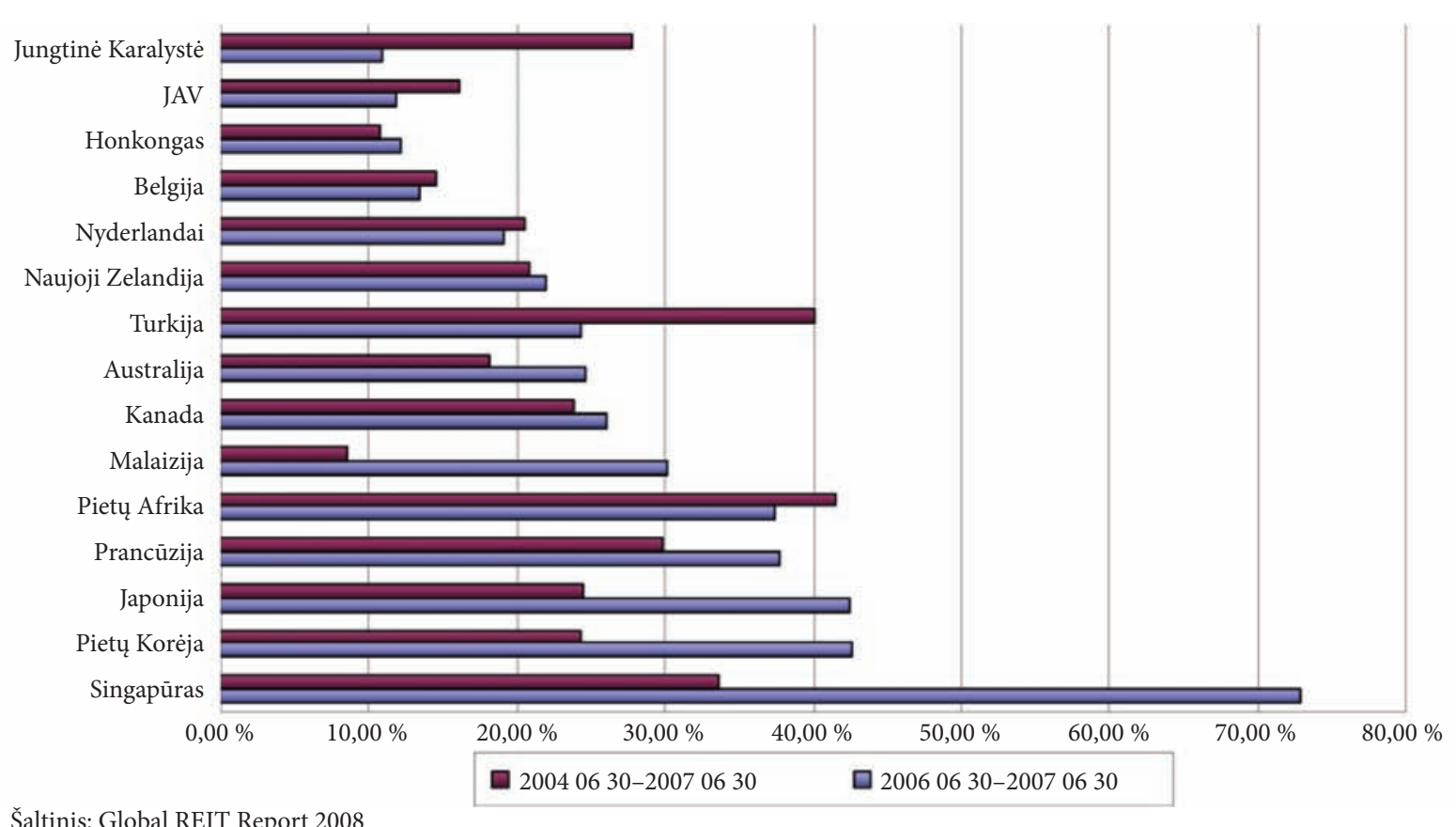

Šaltinis: Global REIT Report 2008

5 pav. REIT pelningumas

Fig. 5. Total return on REITs

\section{Nekilnojamojo turto investiciniai fondai kaip investicijų portfelio diversifikavimo priemonè}

Investicijų portfelio rezultatus lemia daug ịvairiausių veiksnių - nuo mikroekonominių iki tarptautinių politinių sprendimų. Didžioji dauguma šių veiksnių investicinių fondų atžvilgiu yra išoriniai, todèl fondai negali jų valdyti ar kitaip daryti jiems ịtaką. Svarbiausias investicinių fondu valdomas veiksnys yra investicinio fondo struktūra.

Investicijų portfelio struktūrai pagrịsti tradiciškai taikomas toks kriterijų derinys:

- investicijų pelningumas;

- pelningumo svyravimas, kuri iprasta išreikšti standartiniu pelno nuokrypiu ir traktuoti kaip rizikos rodikli;;

- investicijų i i ivairių rūšių turtą pelningumo koreliacija.

Nepaisant didelio praktikų ir teoretikų susidomèjimo, nemažų jų pastangų, nèra sukurtų patikimų šių rodiklių prognozavimo metodų. Iprasta, apeliuojant į tokio masto reiškinių inertiškumą, pasikliauti retrospektyviniais duomenimis (Imperiale 2002). Taigi pažiūrèkime, kaip per tokiu kriterijų prizmę investicijų i i tivairių rūšiu turtą fone atrodo nekilnojamojo turto investiciniai fondai. Apibendrintas 16 metu retrospektyvinio laikotarpio (1990-2005 metai) pelningumo ir rizikos vaizdas pateiktas 6 pav.

Pagal abu kriterijus nekilnojamasis turtas išsiskiria iš bendro fono. Ypač ryškūs skirtumai smarkesniu augimu pasižymejusiuose regionuose - Šiaurès Amerikoje ir Azijoje.
Kitas aiškiai matomas dėsningumas - didesnị pelningumą lydi didesnè rizika.

Investicijų portfelio struktūros požiūriu ne mažiau reikšmingi investicijų i nekilnojamąji ir kitų rūšių turtą pelningumo koreliacijos duomenys (1 lentelè). Matoma ypač maža nekilnojamojo turto ir grynujų pinigų bei obligacijų pelningumo koreliacija (koreliacijos koeficientas atitinkamai nuo $-0,4 \mathrm{iki}-0,48$ ir $0,0-0,2)$. Nekilnojamojo turto ir akcijų pelningumo koreliacija gerokai didesne - iš bendro fono išsiskiria tik vieno regiono (Šiaurès Amerikos) nekilnojamasis turtas (koreliacijos koeficientas 0,28). Be to, investicijų ị nekilnojamąji turtą Šiaurès Amerikoje pelningumas santykinai mažiau koreliuoja su kitų regionų (Europa, Azija) analogiškų investicijų pelningumu.

Panašūs ir kitų investicijų i̇ ịvairių rūšių turtą pelningumo koreliacijos tyrimų rezultatai (Imperiale 2002; Westerheide 2006). Be to, pastebima koreliacijos mažèjimo tendencija (7 pav.). Ši tendencija ypač ryški Amerikos regione, kur per 20 metų nekilnojamojo turto ir akcijų pelningumo koreliacija sumažèjo apie 3 kartus (žemos kapitalizacijos akcijų koreliacijos koeficientas nuo 0,74 iki 0,26 ir aukštos kapitalizacijos akcijų - nuo 0,64 iki 0,25). Reikia pabrèžti, kad R. Imperiale (2002) ir P. Westerheide (2006) nedideli koreliacijos tyrimų rezultatų skirtumai logiškai paaiškinami, nes atlikti tyrimai skiriasi geografiniu aspektu: P. Westerheide pasaulio, o R. Imperiale - tik Amerikos regiono duomenys.

Aptartieji investicijų ị ivvairių rūšių turtą pelningumo, rizikos ir pelningumo koreliacijos dèsningumai yra svertai 
Grynieji pinigai

Obligacijos (JAV)

Obligacijos (be JAV)

Didelès kapitalizacijos akcijos (JAV)

Mažos kapitalizacijos akcijos (JAV)

Akcijos(be JAV)

Pasaulio nekilnojamasis turtas

Šiaurès Amerikos nekilnojamasis turtas

Europos nekilnojamasis turtas

Azijos nekilnojamasis turtas

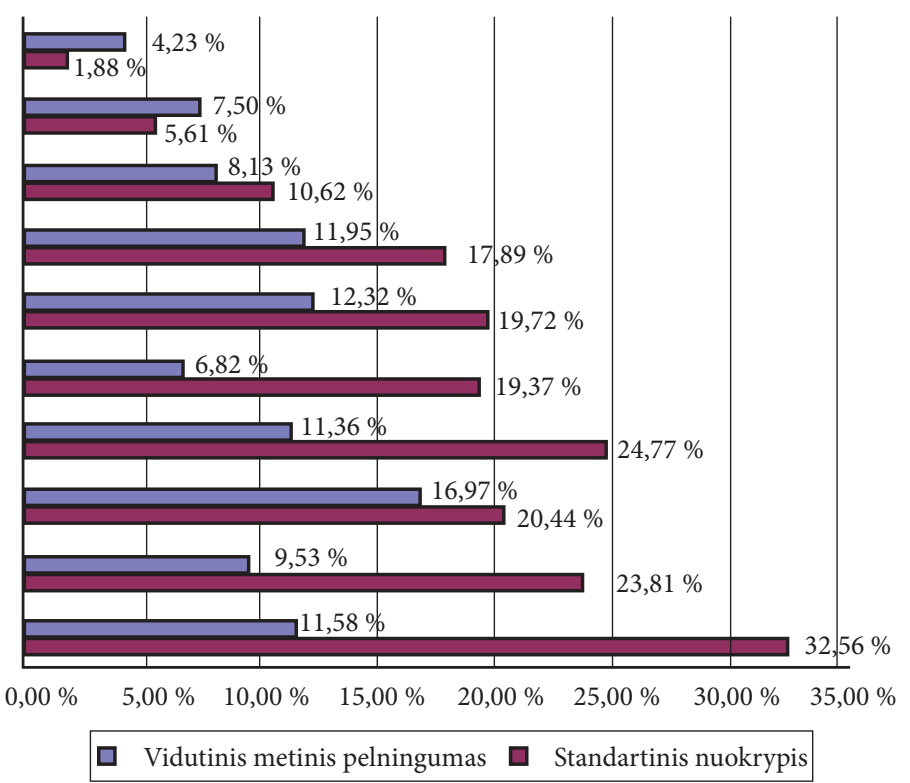

Šaltinis: Idzorek et al. 2006

6 pav. Atskirų rūšių turto pelningumas ir jo standartinis nuokrypis (1990-2005 m.)

Fig. 6. Return and standard deviation of different types of assets (1990-2005)

1 lentelè. Pelningumų koreliacija 1990-2000 m.

Table 1. Correlation of returns 1990-2000

\begin{tabular}{|c|c|c|c|c|c|c|c|c|c|c|}
\hline & $\begin{array}{l}\text { Grynieji } \\
\text { pinigai }\end{array}$ & $\begin{array}{c}\text { Obligacijos } \\
\text { (JAV) }\end{array}$ & $\begin{array}{c}\text { Obligacijos } \\
\text { (ne JAV) }\end{array}$ & $\begin{array}{c}\text { JAV } \\
\text { aukštos } \\
\text { kapita- } \\
\text { lizacijos } \\
\text { akcijos }\end{array}$ & $\begin{array}{c}\text { JAV } \\
\text { žemos } \\
\text { kapita- } \\
\text { lizacijos } \\
\text { akcijos }\end{array}$ & $\begin{array}{l}\text { Akcijos } \\
\text { (be JAV) }\end{array}$ & $\begin{array}{c}\text { Pasaulio } \\
\text { nekilno- } \\
\text { jamasis } \\
\text { turtas }\end{array}$ & $\begin{array}{c}\text { Šiaurès } \\
\text { Amerikos } \\
\text { nekilno- } \\
\text { jamasis } \\
\text { turtas }\end{array}$ & $\begin{array}{c}\text { Europos } \\
\text { nekilno- } \\
\text { jamasis } \\
\text { turtas }\end{array}$ & $\begin{array}{c}\text { Azijos } \\
\text { nekilno- } \\
\text { jamasis } \\
\text { turtas }\end{array}$ \\
\hline $\begin{array}{l}\text { Grynieji } \\
\text { pinigai }\end{array}$ & 1,00 & 0,34 & $-0,17$ & 0,18 & $-0,19$ & $-0,41$ & $-0,48$ & $-0,26$ & $-0,62$ & $-0,40$ \\
\hline $\begin{array}{l}\text { Obligacijos } \\
\text { (JAV) }\end{array}$ & 0,34 & 1,00 & 0,43 & 0,17 & 0,14 & $-0,26$ & 0,04 & 0,20 & $-0,09$ & 0,00 \\
\hline $\begin{array}{l}\text { Obligacijos } \\
\text { (be JAV) }\end{array}$ & $-0,17$ & 0,43 & 1,00 & 0,13 & 0,07 & 0,17 & 0,21 & $-0,01$ & 0,03 & 0,21 \\
\hline $\begin{array}{l}\text { JAV aukštos } \\
\text { kapitalizacijos } \\
\text { akcijos }\end{array}$ & 0,16 & 0,17 & 0,13 & 1,00 & 0,76 & 0,64 & 0,22 & 0,34 & 0,06 & 0,31 \\
\hline $\begin{array}{l}\text { JAV žemos } \\
\text { kapitalizacijos } \\
\text { akcijos }\end{array}$ & $-0,19$ & 0,14 & 0,07 & 0,76 & 1,00 & 0,64 & 0,48 & 0,71 & 0,17 & 0,53 \\
\hline $\begin{array}{l}\text { Akcijos } \\
\text { (be JAV) }\end{array}$ & $-0,41$ & $-0,26$ & 0,17 & 0,64 & 0,64 & 1,00 & 0,66 & 0,28 & 0,56 & 0,76 \\
\hline $\begin{array}{l}\text { Pasaulio } \\
\text { nekilnojama- } \\
\text { sis turtas }\end{array}$ & $-0,48$ & 0,04 & 0,21 & 0,22 & 0,48 & 0,66 & 1,00 & 0,56 & 0,83 & 0,94 \\
\hline $\begin{array}{l}\text { Šiaurès } \\
\text { Amerikos } \\
\text { nekilnojama- } \\
\text { sis turtas }\end{array}$ & $-0,26$ & 0,20 & $-0,10$ & 0,34 & 0,71 & 0,28 & 0,56 & 1,00 & 0,30 & 0,44 \\
\hline $\begin{array}{l}\text { Europos } \\
\text { nekilnojama- } \\
\text { sis turtas }\end{array}$ & $-0,62$ & $-0,09$ & 0,33 & 0,06 & 0,17 & 0,56 & 0,83 & 0,30 & 1,00 & 0,68 \\
\hline $\begin{array}{l}\text { Azijos nekil- } \\
\text { nojamasis } \\
\text { turtas }\end{array}$ & $-0,40$ & 0,00 & 0,21 & 0,31 & 0,53 & 0,76 & 0,94 & 0,44 & 0,68 & 1,00 \\
\hline
\end{tabular}

Šaltinis: Idzorek et al. 2006. 


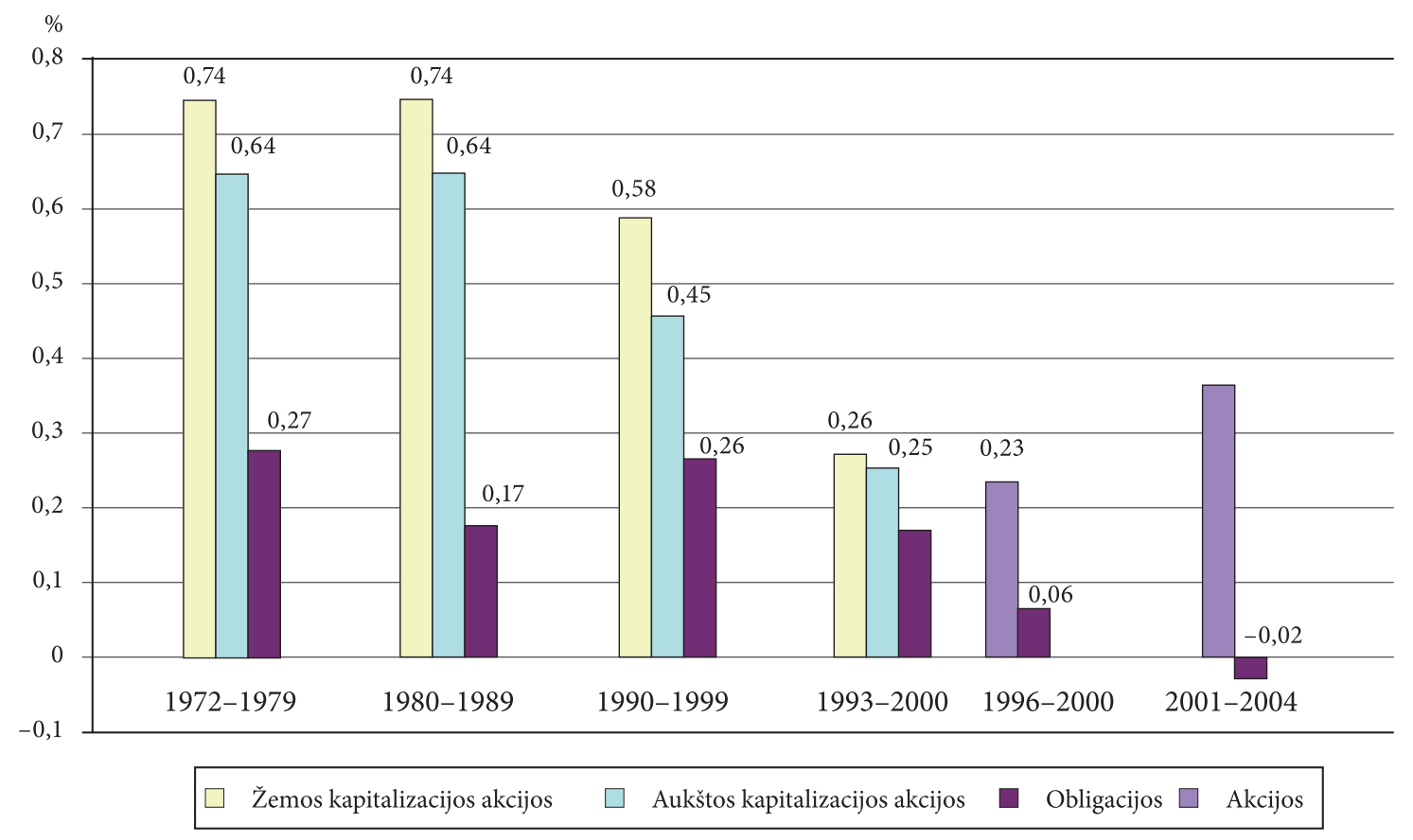

Šaltinis: Imperiale 2002; Westerheide 2006

7 pav. Investicijų i nekilnojamojo turto investicinius fondus ir kitų rūšių turtą pelningumo koreliacija

Fig. 7. Correlation of returns on REIT with other types of investment

pagrindžiant investicijų portfelio struktūrą. Klasikinis investicijų portfelis - akcijų ir obligacijų derinys. Kaip matyti iš aptartų tyrimų rezultatų, ilgalaikis obligacijų pelningumas mažesnis nei akcijų, bet obligacijoms būdinga mažesnè rizika. Be to, akcijų ir obligacijų pelningumo koreliacija santykinai maža. Todèl jų derinys gali sumažinti investicijų portfelio pelningumo svyravimus ir padidinti bendrą kiekvienam prisiimtam rizikos vienetui tenkantị pelną. Tuo pačiu tikslu vis dažniau ị investicijų portfelį itraukiama ìvairesnių rūšių turto, ne tik akcijų ir obligacijų.

Šiuo aspektu ịdomūs ir naudingi R. Imperiale (2002) investicijų portfelio struktūros modeliavimo, siekiant išsiaiškinti pelningumo padidinimo ir rizikos svyravimo galimybes, rezultatai. Modeliuota naudojant faktiškus JAV kapitalo rinkos duomenis. Modeliavimo būdu bandyta nustatyti investicijų portfelio rezultatų pokyčius kaip reakciją i portfelio struktūros pokyčius. Atlikti trys eksperimentai, kiekvienas su skirtingu pagal turto rūšis investicijų portfeliu.

Pirmojo eksperimento investicijų portfelio sudètis tokia: aukštos kapitalizacijos akcijos (pagal S\&P 500 indeksą), dvidešimties metų JAV vyriausybès obligacijos, trisdešimties dienų JAV iždo vekseliai. Tokio klasikinès struktūros investicijų portfelio (50 proc. aukštos kapitalizacijos įmonių akcijų, 40 proc. vyriausybès obligacijų ir 10 proc. iždo vekselių) vidutinis metinis 1972-2000 metų laikotarpio pelningumas buvo 11,8 proc., o rizika - 11,2 proc. Modeliuojant akcijų ir obligacijų dali sumažinus po 5 proc. ir pridejus
10 proc. nekilnojamojo turto investicinių fondų, portfelio pelningumas padidejja iki 12 proc., o rizika sumažèja iki 10,9 proc. Sumažinus akcijų ir obligacijų dali po 10 proc. ir pridejus 20 proc. nekilnojamojo turto investicinių fondų, portfelio pelningumas padideja iki 12,2 proc., o rizika sumažeja iki 10,8 proc. (8 pav.).

Antrasis eksperimentas atliktas su klasikiniu obligacijų portfeliu (90 proc. dvidešimties metų JAV vyriausybès obligacijų ir 10 proc. trisdešimties dienų JAV iždo vekselių). 1972-2000 m. tokio investicijų portfelio pelningumas buvo 9,5 proc., o rizika - 11,3 proc. Modeliavimo metu obligaciju dali sumažinus 10 proc. ir pridejus 10 proc. nekilnojamojo turto investicinių fondų pagal NAREIT vertybinių popierių indeksą, metinis pelningumas išauga iki 9,9 proc., o rizika sumažejja iki 10,6 proc. Sumažinus obligacijų dalį 20 proc. ir pridejus 20 proc. nekilnojamojo turto investicinių fondų, portfelio pelningumas padideja iki 10,3 proc., o rizika sumažeja iki 10,3 proc. (9 pav.).

Trečiojo eksperimento investicijų portfelio sudètis: žemos kapitalizacijos įmonių akcijos (Ibbotson JAV žemos kapitalizacijos įmonių akcijos nuo 0 iki 20 proc.); aukštos kapitalizacijos įmonių akcijos (pagal S\&P 500 indeksą nuo 15 iki 60 proc.), obligacijos (dvidešimties metų JAV vyriausybės obligacijos nuo 5 iki 40 proc.); tarptautinių įmonių akcijos (Morgan Stanley Capital International Europos, Azijos ir Tolimųjų Rytų indeksas nuo 0 iki 20 proc.); iždo vekseliai (nuo 0 iki 15 proc.). Naudojant 1993-2000 m. laikotarpio faktinius duomenis, modeliavimo metu investicijų portfelio 


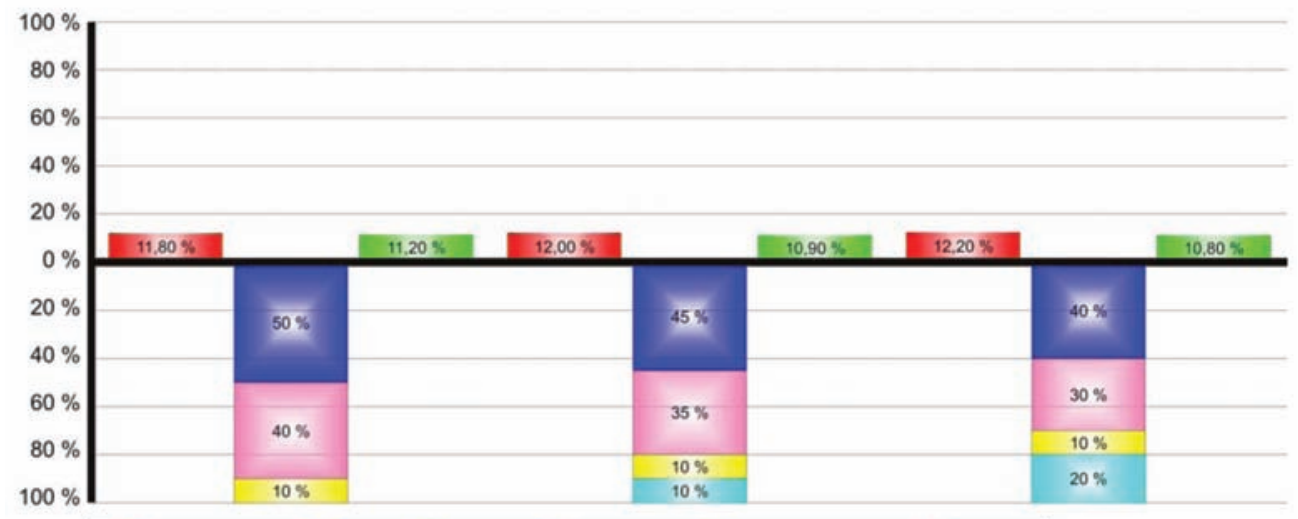

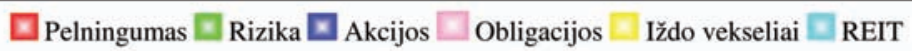

Šaltinis: Imperiale 2002: 69

8 pav. Pirmojo eksperimento rezultatai

Fig. 8. Results of the first simulation

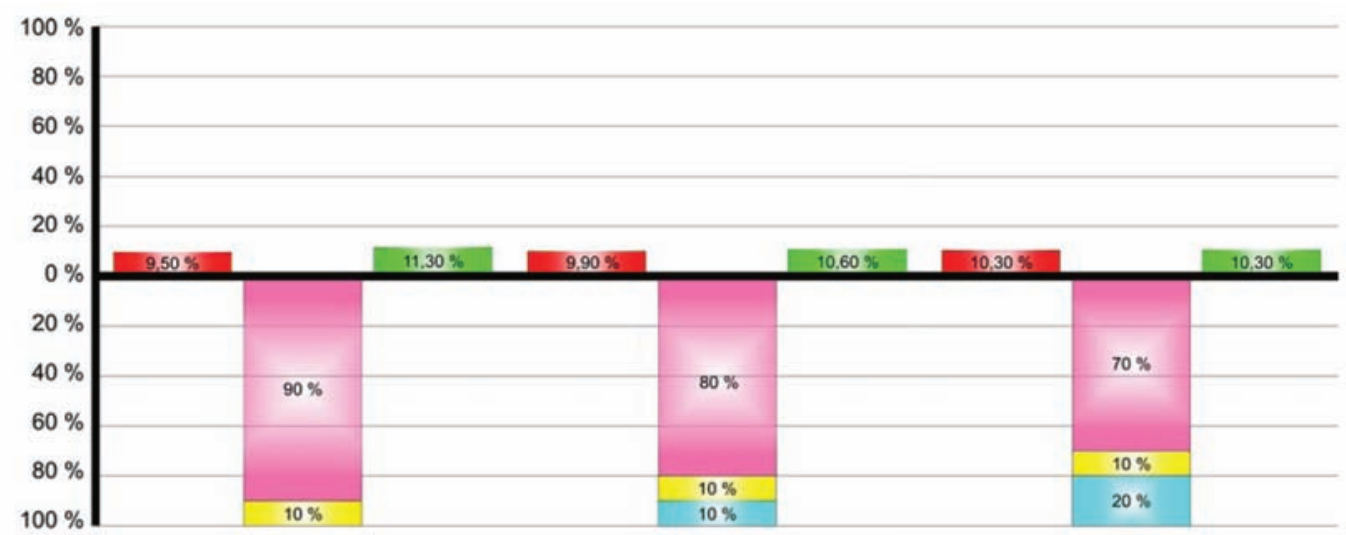

口Pelningumas $\square$ Rizika $\square$ Obligacijos $\square$ Iždo vekseliai $\square$ REIT

Šaltinis: Imperiale 2002: 70

9 pav. Antrojo eksperimento rezultatai

Fig. 9. Results of the second simulation

2 lentelè. Trečiojo eksperimento rezultatai

Table 2. Results of the third simulation

\begin{tabular}{|c|c|c|c|c|c|c|}
\hline \multirow[t]{2}{*}{ Portfelio sudedamosios dalys } & \multicolumn{6}{|c|}{ Portfelis } \\
\hline & 1 & 2 & 3 & 4 & 5 & 6 \\
\hline Žemos kapitalizacijos akcijos & $0 \%$ & $0 \%$ & $14 \%$ & $0 \%$ & $0 \%$ & $11 \%$ \\
\hline Aukštos kapitalizacijos akcijos & $26 \%$ & $45 \%$ & $60 \%$ & $19 \%$ & $39 \%$ & $60 \%$ \\
\hline Obligacijos & $19 \%$ & $17 \%$ & $5 \%$ & $36 \%$ & $31 \%$ & $5 \%$ \\
\hline Tarptautinių rinkų akcijos & $20 \%$ & $18 \%$ & $1 \%$ & $20 \%$ & $20 \%$ & $14 \%$ \\
\hline Iždo vekseliai & $15 \%$ & $0 \%$ & $0 \%$ & $15 \%$ & $0 \%$ & $0 \%$ \\
\hline Nekilnojamojo turto investiciniai fondai (REIT) & $20 \%$ & $20 \%$ & $20 \%$ & $10 \%$ & $10 \%$ & $10 \%$ \\
\hline Tiketinas pelningumas & $12,20 \%$ & $14,50 \%$ & $16,10 \%$ & $11,50 \%$ & $13,90 \%$ & $15,90 \%$ \\
\hline Standartinis nuokrypis & $5,50 \%$ & $7,50 \%$ & $10,50 \%$ & $5,50 \%$ & $7,50 \%$ & $10,50 \%$ \\
\hline
\end{tabular}

Šaltinis: Imperiale 2002: 74-75 
dėmenys ịvairiu santykiu buvo keičiami nekilnojamojo turto investiciniais fondais ir modeliuojamas pelningumas bei rizika. Modeliavimo rezultatų fragmentas pateiktas 2 lentelèje.

Pateikti modeliavimo rezultatai leidžia teigti, kad ịvairių investicijų portfelio struktūrinių proporcijų portfelị papildžius nekilnojamojo turto investiciniais fondais galima gerokai padidinti investicijų portfelio pelningumą ir sumažinti riziką. Žinoma, ir šiuo atveju aktualus išlieka investicijų portfelio struktūros nustatymas investicijų objektų lygmeniu. Atskirų nekilnojamojo turto objektų, panašiai kaip ir atskirų i̇monių akcijų, pelningumo ir rizikos rodiklių svyravimo diapazonas ypač didelis.

\section{Išvados}

Pasaulyje vyrauja investicinių fondų ívairovès ir masto didejimo tendencija. Šioje srityje vis tvirtesnes pozicijas igauna nekilnojamojo turto investiciniai fondai. Dèl jų vietos ir vaidmens kapitalo rinkoje specialioje ir mokslineje literatūroje išsakomos prieštaringos nuomonès.

Pasaulio investicinių fondų retrospektyvinių duomenų analizè per svarbiausių investicijų portfelio sudarymo kriterijų prizmę leidžia konstatuoti tokius dèsningumus nekilnojamojo turto investicinių fondų atžvilgiu:

- investicijų i nekilnojamojo turto investicinius fondus pelningumas didesnis už grynųjų pinigų bei obligacijų pelningumą ir artimas investicijų ị akcijas pelningumui;

- pagal rizikos rodikli, kuris skaičiuojamas kaip pelningumo svyravimų standartinis nuokrypis, nekilnojamojo turto investiciniai fondai nusileidžia investicijoms ị visų kitų rūšių turtą;

- nekilnojamojo turto investicinių fondų ir grynųjų pinigų, taip pat obligacijų pelningumo koreliacija maža, nekilnojamojo turto investicinių fondų ir akcijų pelningumo koreliacija gerokai didesnè, išskyrus Šiaurès Amerikos regioną, kuriame investicijų i nekilnojamąji turtą pelningumas mažiau koreliuoja su kitų regionų (Europa, Azija) analogiškų investicijų pelningumu.
Nustatyti dėsningumai leidžia teigti, kad nekilnojamojo turto investiciniai fondai yra patraukli investicijų portfelio diversifikavimo priemonè, leidžianti pasiekti priimtiną pelno ir rizikos kompromisą.

\section{Literatūra}

Čepinskis, J.; Kuzmickas, D. 1997. Investiciniai fondai ir finansų valdymas, Organizaciju vadyba: sisteminiai tyrimai 4: 7-23.

Global REIT Report. 2008. REIT Market Review 2007. Ernst \& Young.

Idzorek, T.; Barad, M.; Meier, S. 2006. Commercial Real Estate: The Role of Global Listed Real Estate Equities in a Strategic Asset Allocation (prepared for the National Association of Real Estate Investment Trusts). Ibbotson Association.

Imperiale, R. 2002. Getting Started in Real Estate Investment Trusts / REITs. New York: John Wiley \& Sons, Inc. 288 p.

Kancerevyčius, G. 2006. Finansai ir investicijos. Kaunas: Smaltija. 864 p.

Lietuvos Respublikos investicijų i̇statymas. 1999. Valstybès žinios, Nr. 66-2127

Lietuvos Respublikos kolektyvinio investavimo subjektų įstatymas. 2003. Valstybès žinios, Nr. 74-3424.

Mačerinskienė, I.; Volodzkienė, L. 2006. Investiciniu fondu klasifikavimo ypatumai, iš Business Development Possibilities in the New European Area: tarptautines mokslines konferencijos medžiaga. Vilnius: VU leidykla, 289-302.

Snieška, V.; Pekarskiené, I. 1999. Investiciniai fondai: užsienio šalių patirtis ir veiklos perspektyvos Lietuvoje, Socialiniai mokslai 1: 73-78.

Vertybiniu popieriu komisija. 2006. Investuotojų švietimas [žiūrèta 2006-11-06]. Prieiga per internetą: <http://www. vpk.lt/ svietimas/>.

Westerheide, P. 2006. Cointegration of Real Estate Stocks and REITs with Common Stocks, Bonds and Consumer Price Inflation - an International Comparison. Centre for European Economic Research. Discussion Paper No 06-057.

Worldwide Number Of Mutual Funds. 2007. ICI Fact Book [žiūrèta 2007-12-12]. Prieiga per internetą: <http://www.icifactbook. org/pdf/07_fb_table49.pdf>.

Juozas BIVAINIS. Doctor Habil, Professor, Head of Dept of Social Economics and Management, Vilnius Gediminas Technical University. He is the author of over 200 scientific works. Research interests: intensification of economic development, business management theory, economic legislation.

Lina VOLODZKIENĖ. Doctoral student of Business Management Faculty, Vilnius Gediminas Technical University. Research interests: investment in real estate, real estate investment trusts, modern theories of economics and business management. 